\title{
Hearing Glenn Gould's Body: Corporeal Liveness in Recorded Music
}

\author{
Paul Sanden
}

\section{Introduction: Liveness, Mediatization, and Glenn Gould's Recordings}

Live music does not exist without its recorded other. In other words, the concept of liveness in music was unknown until there was something not live-recordings-with which to compare it. Sarah Thornton describes the conventional ideology of liveness, which derived from a live/recorded binarism, as historically giving "positive valuation to ... performed music. [The word 'live'] soaked up the aesthetic and ethical connotations of life-versus-death, human-versus-mechanical, creative-versus-imitative . . . Liveness became the truth of music, the seeds of genuine culture. Records, by contrast, were false prophets of pseudo-culture" (1995:42). Liveness, at least as historically constructed, signified the authenticity of human musical production and performance, always considered in contrast with the artifice of electronic reproductions.

While this rather straightforward live/recorded binarism still informs some Western concepts of liveness today, many recording and performance situations are far more complex than such a binarism will allow. So-called live recordings provide a simple example: on the one hand, those who listen to such recordings are not immersed in the same atmosphere of sights, smells, tactile sensations, or even sounds (because, despite the best intentions of its producers, no recording can ever exactly reproduce the sounds it supposedly captures) that the attending audiences experienced at the time of performance/recording. On the other hand, the liveness of these recordings is thought to consist in their apparently faithful representations of performances that took place in the presence of these audiences. Television broadcasts, rock music performances, and various forms of electroacoustic music (among many other musical contexts) all similarly present mixtures of electronic mediation and some semblance of liveness. ${ }^{1}$ In many instances, then, liveness persists even within what I will call mediatized music, or more specifically mediatized performance.

I borrow the term mediatized from Philip Auslander, who in turn borrows it from Jean Baudrillard (1981) to indicate "that a particular cultural object is a product of the mass media or of media technology" (1999:5). 
Auslander, like Baudrillard, recognizes the mass media as the dominant form of cultural production, and thus as a "vehicle of the general code in a way that live performance is not (or is no longer)" (1999:5). Use of the term mediatized thus indicates not only the deployment of electronic technology in the production of culture, but also the ways in which this very deployment brings that cultural production into a much wider network of dominant social and economic practices. Mediatization recognizes the deeper implications of technology's ubiquity in a way that a more neutral term like mediation cannot. My own use of the term mediatization is slightly but significantly reconfigured from that of Auslander, in that while I still rely on the term's ability to denote the profound effects of electronic media on the musical process, I also believe there are many forms of mediatized music that in fact challenge the "dominance of a single code" (Auslander 1999:5) informing Baudrillard's thinking and to a lesser extent that of Auslander himself. This is mainly because much mediatized music exists largely outside the economies of mass circulation so prominently explored in their usage, even though much of it is produced using popular contemporary forms of media technology.

So much of our performance tradition has become mediatized that we must, as music scholars and practitioners, re-examine old distinctions between "live" and "not live." In this sense, then, I propose that we understand liveness not so much as a designation of "non-mediatization," but rather as a designation of a trace of that which could be live, in the face of the threat of further or complete mediatization. As Simon Emmerson (2007:93) suggests, this trace of liveness may even be imagined. Arguably, the important thing is not whether sound was actually physically produced by a living being, but whether we perceive some sort of live presence in those sounds. Liveness is a perception, guided by the different ways it may be evoked inside cultural discourse and practice.

In trying to understand our perceptions of liveness, we may be guided by Auslander's suggestion that the "exact meaning and cultural importance [of liveness] are subject to change, especially in relation to technological development" (2005:8). Liveness exists as a fluid concept among different people and at different times, rather than as a concrete ontological category with well-defined essential characteristics. This very fluidity of the concept of liveness is, in part, what makes this issue so complex and worthy of further scrutiny. As Auslander argues, understandings of liveness may change as the technologies implicitly invoked by this concept change. Under such circumstances, the complexities of the current art music soundscape are no longer fully served by the simplistic understanding of live music as "not recorded." 
In light of its fluidity, how should we define liveness, if not simply as an absence of obvious electronic mediation? I suggest above that liveness be understood as a designation of a trace of that which could be live, even within a mediatized musical context. In any given set of circumstances, this trace may be manifest in a number of ways. Elsewhere (Sanden 2008) I enumerate seven different potential categories of liveness, according to different ways that liveness has been discussed within the scholarly literature. ${ }^{2}$ In this essay, I will focus on what I call corporeal liveness: liveness invoked by music's connection to an acoustic sounding body, usually that of a human performer. Of all the accounts of musical liveness within the literature, most rely at least in part (if not always explicitly) on definitions of live performance as somehow corporeally based. This is primarily because it is difficult (if not impossible) to discuss concepts of live performance without eventual recourse to the body's role in-or conspicuous absence from-the musical contexts under discussion. In many cases, the dislocation of sound from its physical source (the musician originally producing that sound) causes observers to lament the loss of liveness from the recorded musical experience.

A focus on musically performing bodies calls attention to another highly entrenched binarism within musical discourse: what Suzanne Cusick (1994) and others have identified as the "mind/body problem." This ideological binarism leads to an understanding of music as a collection of works, ideas, and interpretations (products of the mind), but not of actions, tactile sounds, and physical gestures (experiences of the body). The mind/body binarism in musical discourse is problematic in its denial of individual performing bodies, which results in the neglect of the social act of performance in much of our musical scholarship. This essay, then, will engage in what Elisabeth Le Guin (2006) calls a "carnal musicology" - a study of music as a physically enacted phenomenon-by discussing the mind/body binarism with respect to the pianist Glenn Gould.

Gould has long been characterized, by himself and by others, as a thinking musician. The recording studio, he felt, offered him the greatest opportunity to construct performances that reflected his best ideas-interpretations formulated in his mind - about musical works, particularly because it afforded him the ability to reflect on his different recorded interpretations during the production process. Yet his recordings also present us with very tangible traces of corporeality, so much so that to listen to them is to hear a body performing, as long as we make room in the Gould mythology for a musician whose playing is as important as his thinking. Moreover, by addressing the corporeal liveness so evident in Gould's recorded work, I present a reading of recordings - those so-called agents of disembodiment - in which a body still sounds. In what follows, I will discuss the mind/body problem in 


\section{Current Musicology}

music, first broadly, and then with respect to Gould. I will then address the place of recordings within a mind/body context, arguing that despite many assertions to the contrary, recording and disembodiment are not necessarily inextricably linked. Finally, I will discuss several of Gould's recordings, with an ear for traces of Gould's own performing body-his corporeal liveness.

\section{Glenn Gould: Mind and Body}

The centrality of musical thinking (at the expense of musical physicality) is not unique to the case of Glenn Gould; rather, it is part of a long tradition. Within the history of Western art music, and particularly within scholarly writing associated with that history, music's most significant properties have long been linked to the realm of mental activity. People who adhere to this concept view music as the communication of ideas, abstract structures, complex patterns, etc., all of which are situated in musical works. Once composed, these works take on metaphysical properties, existing somehow in and of themselves, awaiting their representation in performance. ${ }^{3}$ Yet until recently, these performances were not often considered important on their own-as physical processes of sound creation and communication, carried out by musically laboring bodies. Rather, each performance was (and often still is) judged according to how successfully it communicated the ideas that constitute the composer's work.

The primacy of mind in musical discourse has emerged in various guises, as has been demonstrated convincingly by several writers. In addition to Cusick's (1994) condemnation of the mind/body problem, and Le Guin's (2006) commendable example of carnal musicology, the issue is neatly addressed by Richard Leppert (1993:96-101), who demonstrates that in many eighteenth-century treatises the "essential" qualities of music were held to exist in the mathematical relationships between the intervals of the Western tonal scale. This reduction of music to its mathematical properties presents an entirely knowable music, in line with the wider appeals to order and reason so prevalent during the European Enlightenment. The association of music and mind was also prominent within Romantic musical aesthetics, even if the nineteenth-century rhetoric surrounding this concept was more concerned with genius than with the rationality of the eighteenth century. Writing in 1813 about Beethoven's instrumental music, for example, E. T.A. Hoffmann repeatedly remarks on Beethoven's unrivalled genius, citing the "inner continuity" and "internal structure" of Beethoven's compositions as the true marks of their worthiness. Hoffmann emphasizes that the structural relationships found in Beethoven's compositions (for example, the unity of motivic materials across different movements of a work) are products of a 
superior intellect and, furthermore, that "a deeper relationship which does not reveal itself in this way speaks at other times only from mind to mind, and it is precisely this relationship that ... imperiously proclaims the selfpossession of the master's genius" (1998:1195-6; my emphasis). ${ }^{4}$

Reference to the nineteenth-century cult of genius, with Beethoven as its central figure, also raises the issue of the contemporaneous cult of the virtuoso, whose central figures were Franz Liszt and Nicolò Paganini. Although virtuosi's physical attributes were highly fetishized in the popular imagination (for instance, Liszt's hands were cast in molds several times during his life), I suggest that bodies remained "weaker" symbols of music's significance than brilliant minds. This can be explained best, perhaps, in light of Jacques Derrida's concept of phallogocentrism: the privileging of reason and mind, and the patriarchal hierarchy of that privileging, in Western epistemology. ${ }^{5}$ As Leppert (2007) demonstrates, music became gradually remasculinized throughout the nineteenth century, after centuries of association with feminine qualities. While Liszt did much in his own right to masculinize the piano, his gender image as a performer remained somewhat ambiguous, as did those of nineteenth-century performers in general. Furthermore, the individual responsible for masculinizing music more than any other at this time was not a virtuoso figure (or at least not just a virtuoso figure) but Beethoven, the brooding and brainy musical genius par excellence (Leppert 2007:151-63). ${ }^{6}$

These arguments depict a tradition in which the most important aspects of canonical Western art music (what is transmitted "from mind to mind") are found in its abstract compositional structure, created by relations between pitches (and to a lesser extent, rhythms). Within this scenario, anything not associated with these organizational structures-any noise, to use Jacques Attali's (1985) term-is an unwanted distraction, at best. In Attali's usage, noise does not refer just to the sonic phenomenon of "unmusical" sound, but also to whatever detracts from the organizational principles of music as they have historically been observed in Western musical practices. ${ }^{7}$ Gould comes quite honestly, then, to his own firm entrenchment within a mindcentered concept of music, which is clear in his writings and interviews. He adheres to such a paradigm to the extent that he considers the noise of his body (both literally and in Attali's sense) to be quite incidental to his mental approach to music.

Before delving too far into Gould's own remarks, it is worth considering the way he has usually been presented in the popular and scholarly media, for our perceptions of Gould the icon (informed largely by these media) most definitely influence how we listen to Gould the musician. Consider the following promotional lines, included by Columbia Masterworks on the back of several of Gould's LPs from the 1960s: 


\section{Current Musicology}

When Mr. Gould made his recording debut, with the immensely difficult and demanding Goldberg Variations of Bach, his performance was so masterful that it elicited bravos from critics who found it difficult to believe that a young artist could offer such probing, sensitive interpretations. Mr. Gould has further demonstrated his rare understanding of Bach's music with recordings of the complete Partitas ... An avid reader, he prefers the works of Mann, Kafka, Tolstoy, Dostoyevsky and Nietzsche, and is himself a writer of several works on the masters of the Viennese school. $\left(\right.$ Gould 1963) ${ }^{8}$

Not only are we told that Gould's greatest musical strengths lie in his "probing" intellect and in the depths of his "rare understanding," but also that when he is not playing the piano, he further engages his mind by reading some of the most intellectually challenging literature in the Western canon and writing about the most cerebral music of the twentieth century. ${ }^{9}$

A few years earlier, Ross Parmenter of the New York Times had presented a similar portrayal of Gould, following an engagement at the Stratford Summer Music Festival in which Gould spoke to the audience about the music he was performing. Parmenter attributed the success of the evening both to Gould's abilities on the piano and to his gifts as a "thinker":

Mr. Gould is as gifted a musical thinker as he is a pianist ... Mr. Gould's comments [about the music of Berg, Schoenberg, and Krenek] gave the key to his own playing of the works. He understood their motivic coherence so well that each note seemed a vital part of a satisfying and emotionally expressive unit. (1956:26)

Focus on the significance of Gould's intellectual abilities has reached beyond popular journalism. It has also become central to many of the lengthier studies of Gould's work, particularly those that deal more with his writings than with his playing. For instance, the first book-length study of Gould, Geoffrey Payzant's Glenn Gould: Music and Mind (1978), announces its bias in its title. John P. L. Roberts's The Art of Glenn Gould: Reflections of a Musical Genius (1999) expresses a similar bias in its title while also promoting a compatible image-one of Gould in contemplation-through its cover art. Even though Gould sits at the piano in this picture, he sits sideways with his left arm resting on the music stand and his gaze averted from the instrument, giving the impression perhaps that the instrument itself is merely the necessary tool by which he imparts to his audience his deep understanding of the music. ${ }^{10}$ In other words, Gould playing is not nearly as important as Gould thinking. ${ }^{11}$

For all of this focus on Gould's mind, however, it is important to note that his performing body has seldom been ignored. Rather, Gould's physical actions have been cause for much concern and criticism; his body has thus been portrayed as an obstacle for his mind to overcome. ${ }^{12}$ To be sure, Gould's 
physical command of the piano was never questioned and regularly received acclaim from critics and other listeners. I suggest, however, that praise for his manual dexterity has often been overshadowed by praise for his mental dexterity and certainly by criticism of his other physical mannerisms. In this way Gould's body is depicted not so much as an essential part of his music making, but rather as a potential distraction from it.

Gould's unusual stage demeanor during his performing years seems to have drawn the most negative press in this respect. Reviewers typically began by drawing attention to his idiosyncratic performance mannerisms (whether they enjoyed the program or not). Only after going through an entire litany of his physical quirks would they proceed to evaluate the recital. New York Times critic Harold C. Schonberg offers a particularly engaging description:

At about 8:45 last night Glenn Gould, the cadaverous Canadian, shambled from the wings at Carnegie Hall, managed to get to the piano (which was mounted on small blocks), slumped back on a bench that seemed about three inches off the ground, put his feet on the pedals and also a throw rug underneath them, put a look of ecstatic suffering on his face, and played much of his program very beautifully.

He subsequently went through his familiar eccentricities, which included singing (he was not in especially good voice this time), conducting, and crossing his left leg over his right. (1959:14)

Perhaps the most effective promotion of this dual image of Gould-one of formidable mind and imperfect body-came from Gould himself. ${ }^{13}$ Gould repeatedly stated in interviews and in his own writings that for him the most important aspect of any piece of music was its structure. He asserted, moreover, that his interpretation of such structures was primarily a mental process, quite distinct from the physical act of playing the piano. He often told his friend and colleague, John P. L. Roberts, that he could "practise in his head," and that he "believed the piano had to be played with the mind" (Roberts 1999:26). Corporeal activity, then, become secondary to cerebral activity. This is not to say that Gould completely ignored the tactile aspects of playing the piano, or that he never spoke of them. On the contrary, his own views on the performance of the piano itself were based far more on how the instrument felt under his fingers than on the sounds he could get from it (Bazzana 2003:197-98). He often stated that his own distinctive approach to playing the piano grew out of the tactile way in which he learned to play the organ. He explains that when playing the organ, the whole effect of clarity of line, of detached sound, has got to be achieved by a lifting of the finger after the note has been struck and not an attack on the note before it has been struck. 


\section{Current Musicology}

This was the method of playing which of course I learned on the organ and which I simply transferred to the piano, a method which involved minimal movement of the fingers, really, and which-I'm sorry to reduce this to something so physical, but this is really what it was-and a method which began by starting at the key rather than above it, and [in] which no amount of excessive force could be brought to bear on the piano. (Gould and Rich 1999:139; my emphasis)

Gould reveals two crucial points here. First, even his physical approach to the instrument is only as "physical" as absolutely necessary, in that it involves as little movement as possible. In addition to the "minimal movement of the fingers," he avoids any "excessive force" in his playing. ${ }^{14}$ Second, and I think more significantly, Gould feels the need to apologize for speaking about his playing in such blatantly physical terms. He does modify this account somewhat in other interviews, making clear that the physical demands of playing the piano are worked out in the mind long before they are ever acted out at the instrument. In one instance, he speaks of "practicing" mentally while away from the piano for long periods of time, and states that "one carries the fingerings in one's head at all times" (Gould and Aikin 1999:269-70).

Gould was able to further reconcile his tactile approach to the instrument with his mind-centered concept of music because he felt that since the real business of music making went on in the mind, it was not tied to performance on any particular instrument. Put another way, physicality was important to Gould only insofar as it allowed him to realize a piece on the piano, which was secondary to understanding the piece in its own abstract and disembodied state. Gould's praise of pianist Sviatoslav Richter resonates very strongly with the image he projected of himself. As such, it helps to further clarify his views on the physical mechanics of making music. $\mathrm{He}$ argues that musicians can be divided into two categories: "those who seek to exploit the instruments they use, and those who do not." Richter, he believes, belongs to the second category, which

includes musicians who try to bypass the whole question of the performing mechanism, to create the illusion, at any rate, of a direct [mental] link between themselves and a particular musical score and who, therefore, help the listener to achieve a sense of involvement, not with the performance per se, but, rather, with the music itself ...

[It] is possible ... to achieve such a perfect liaison with the instrument that the mechanical process involved becomes all but invisible - totally at the service of the musical structure-and that the performer, and consequently the listener, is then able to ignore all superficial questions of virtuosity or instrumental display and concentrate instead on the spiritual qualities inherent in the music itself. (Gould 1999b:52-53) 
In a similar vein, Gould's comments about the tactile aspects of any particular piece were often quickly followed by a comment about the more important issue of analysis. Gould's description of Jacques Hétu's Variations for piano provides an example:

Hétu's flair for the instrument is unmistakable. Everything works and sounds and lies rewardingly beneath the fingers. Yet, the impressive thing about these Variations is that despite their unabashedly theatrical inclination, they are held together by a sure sense of the purely musical values inherent in their material. (Gould 1967)

Gould then explains that the material in question is a twelve-tone row and goes on to discuss the tonal qualities inherent in this row. To Gould, then, "purely musical values" are to be found in the analysis of a piece; not in the physical act of playing it.

Gould's views on the importance of analytical thought in music must also be understood in relation to his thoughts about the limitations and frailty of his own body. As a particular extension of his admitted hypochondria, Gould lived in constant fear of losing all control of his hands.$^{15}$ He made headlines in 1960 when he sued the Steinway and Sons piano company for an incident involving one of their technicians, who purportedly greeted Gould with a "thump" on the back, causing injury to Gould's left shoulder and hand. ${ }^{16}$ CBS itself was quite eager to share with Gould's listeners his constant concerns about blood circulation in his forearms and hands, in a press release issued with Gould's first Goldberg Variations recording (1956; reprinted in Page 2002).

Regarding his physical eccentricities in performance, Gould also considered them necessary only to the point that they helped him achieve his ideal performance. He once told an interviewer that when it first came to his attention in 1956 that his singing and conducting were distracting to his audiences, he became very self-conscious because he had never before given any thought to his physical appearance during performance. "The whole secret of what I had been doing," he explained, "was to concentrate exclusively on realizing a [mental] conception of the music, regardless of how it was physically achieved" (Gould and Asbell 1999:186).

Gould establishes a clear hierarchy, then, regarding his thoughts about music and his subsequent bodily efforts to represent those thoughts in sound. Clearly, to Gould, a musician's physical actions are only important insofar as they serve his or her mental conception of how a particular work should sound. Gould's views are by no means unique or radical, as they simply reflect the mind-centered concept prevalent for centuries within Western musical epistemology. Gould is notable, however, for how explicitly 


\section{Current Musicology}

he explains this hierarchy. He is also notable, paradoxically, for how much of an inadvertent physical response he clearly had to music despite his own devaluation of music's existence in the physical realm. Gould's willing and almost perverse refusal to acknowledge the significance of his body in his own musical practice, in spite of the overt physicality of his playing, further parallels the immense lack of attention paid to corporeal meaning in so much Western musical thought.

\section{Disembodied Music or Corporeal Liveness? Performances on Record}

If Gould was uninterested in music's corporeal qualities, audio recording would seem to be the perfect medium through which he could exercise his mind-centered approach to performance. While Gould never explicitly stated as much, many others have argued that recorded sound is essentially disembodied sound. John Corbett's description of an "audio-visual disjunction" (1990:84) in recorded music provides a useful introduction to this discussion. For Corbett, popular music consumers' various attempts to reconstitute a visual element in their encounters with recordings (through music videos, album cover art, and audio imaging ${ }^{17}$ ) are a result of the desire to "negotiate the menacing void" left by the removal of the body from recorded musical experiences (1990:85). In popular music, according to Corbett, this body is removed not only visually, but also aurally by echo, compression, ${ }^{18}$ and other recording studio techniques. Ultimately for Corbett, these aural traces also become visual:

The sound of fingers, lips, legs, and nose are all traces of the performer, the absent performer, and they foreground the visual. Echo, by doubling the sound upon itself, and compression, by doing away with unseemly transients, wrench the sound of music from the body of the performer and erase its trace ... [Recordings] appeal to a fantasy of absolutely independent music, where concerns of the image never enter the picture. Lullaby, close your eyes, and good night. (1990:92)

This "fantasy of absolutely independent music" can be linked to the general logocentrism that N. Katherine Hayles argues is indicative of the digital era. She traces this logocentrism back through Western thought to the liberal humanist subject of the late seventeenth century. ${ }^{19}$ Hayles argues that to many modern thinkers, the universe is composed essentially of information, which thus encourages a fantasy comparable to that identified by Corbett:

[T] hat because we are essentially information, we can do away with the body. Central to this argument is a conceptualization that sees information and materiality as distinct entities. This separation allows the construction 
of a hierarchy in which information is given the dominant position and materiality runs a distant second. As though we had learned nothing from Derrida ... embodiment continues to be discussed as if it were a supplement to be purged from the dominant term of information, an accident of evolution we are now in a position to correct. (Hayles 1999:12)

The parallels between Hayles's examples and those from within Western art music (Gould, Beethoven, etc.) are evident. Yet, for many musicologists concerned with reconstituting the value of corporeality in accounts of Western music, their arguments about disembodied sound, like Corbett's, nonetheless revolve around a lack of a certain kind of visual information in a given musical experience. In these cases, perception of performing bodies is equated with seeing those bodies (or at least with constructing mental images of those bodies) ${ }^{20}$ For some writers, the danger of a mind-centered musical perspective coupled with recording is that these recordings thus become an easy method by which listeners "can have the pleasure of the sound without the troubling reminder of the bodies producing it" (McClary 1991:136).

While productive, such accounts of recordings as agents of disembodiment promote an overriding technophobia that ignores the very real potential for sound technology to further increase a listener's engagement with corporeality in mediatized music. When we consider the historic development of sound recording and reproduction technologies, we realize that these technologies were modeled after our own bodies' methods of hearing sound-after the physiology of the human ear (indeed some early sound technologies created by both Clarence Blake and Alexander Graham Bell involved the use of real, dissected, human ears). As Jonathan Sterne argues, "the body is the first communication technology, and ... technologies of listening ... emerge out of techniques of listening" (2003:92). Many such techniques were developed inside the human body (Sterne calls them "techniques of the body") long before technologies outside of the human body were ever conceived of. To assume that sound technologies interrupt the corporeal significance of sounds simply because they remove these sounds from their visual sources is thus to ignore corporeally sensitive techniques of listening that have little if anything to do with sight.

To help rectify this omission, I turn to other writers who have suggested how we might begin to recognize and appreciate performing bodies, even when we lack any visual clues about them. Phenomenologists have long argued that everything we perceive is rooted in a sense of embodiment, since even our minds are physically situated in the world. This idea has also been taken up by music cognition scholars. Marc Leman, for instance, argues that "the subjective world of mental representations is not an autonomous category but a result of an embodied interaction with the physical environ- 


\section{Current Musicology}

ment" (2008:13). ${ }^{21}$ Several writers have followed this line of argument to suggest that, in perceiving music, listeners relate the sounds they hear to their own embodied understandings of their environment. Variations on this argument bear several different labels, including "kinematic empathy" (Todd 1995), "bodily hearing" (Mead 1999), "the mimetic hypothesis" (Cox 2001), and "corporeal signification" (Leman 2008:17-19). ${ }^{22}$ Whatever the label, these concepts all describe a listener making sense of music not abstractly, but through corporeal involvement. The body acts as a mediator between physical sound and mental cognition (Leman 2008).

In this way, for instance, a regular rhythmic pulse within a given piece of music may engage a listener's experiences of regular rhythms within her own body, such as the beating of her heart, or her experiences of walking and running. Moreover, music perception also relies on a listener's embodied understanding of sound production itself. In other words, the recognition that someone struck a drum to produce a particular sound may engage a listener's own understanding of how it feels to make that physical gesture. Arnie Cox (2001) is particularly helpful in explaining this perceptual phenomenon, because he focuses on the sound-producing body. In his account of a "mimetic hypothesis," Cox presents the dual assertion that "1) we understand sounds in comparison to sounds we have made ourselves, and that 2) this process of comparison involves tacit imitation, or mimetic participation, which in turn draws on the prior embodied experience of sound production" (2001:195). ${ }^{23}$

Such theories of corporeal listening are based on the sounds of bodies and on physical responses to sounds, rather than on the act of viewing bodies. As such, they suggest that corporeal liveness - the audible trace of bodies performing - may be evident in musical recordings, even if many choose not to hear it. Furthermore, corporeal perceptions of liveness carry a significance in recorded music that accounts of recordings as disembodied music deny. As Cox argues, "music invites us to participate-both in our imagination, which is automatically informed by embodied experience via tacit mimetic participation, and overtly in the form of such things as toetapping, swaying, dancing, and singing along. The ways in which we respond to the invitation to participate ... are part of how we define ourselves and society" (Cox 2001:206-7). An account of corporeal liveness in recordings, in other words, recognizes recorded music as a form of communication in which the performer (and not just the composer's work) holds great significance, even if this communication is made indirect by the mediation of technology. 


\section{Gould's Body on Record: The Mediatization of Gould's}

\section{Performances}

Before discussing Gould's recordings directly, I will address his statements about the recorded medium, at least as they relate to this notion of communication I have just described. For Gould, music was not about communication between performer and audience. After retiring from the concert stage in 1964, he was asked by interviewers if he missed the direct connection so many performers claim to share with their audiences. ${ }^{24}$ Gould responded that he never felt such a connection when he was concertizing, so he certainly did not miss it now that his performances were confined to recording and broadcast studios. Rather, he viewed the microphone as a "friend," and if anything, felt more communion with it than with any potential audience (Gould and Tovell 1999:80).

Gould was not entirely against the idea of musical communication, but he viewed it as a line of communication that ideally did not involve the performer. To Gould, recordings offered a connection with a much broader audience, but one that was, paradoxically, more intimate than that offered in a live performance setting. His perspective relies once again on understanding the musical work as occupying the place of primary importance. This intimate connection does not take place between performer and listener, but rather between listener and work, and through the work, between listener and composer. Gould felt that one of the strengths of electronic sound technology lay in its ability to present for composers a permanent record of their own interpretations (in the form of electroacoustic works or their own performances) so that they would not have to rely on other performers to get it right. Moreover, Gould argued, listeners will connect more intimately with that work since they "will be forced to come to decisions about the work of art because of the reaction which they themselves receive from it, and for no other reasons" (Gould 1999a:219). Because they are listening privately, in other words, these listeners will generate a response to and an interpretation of the work completely by their own means, and will not be distracted by the responses of their neighbors in a concert hall or by the presence of the performer on stage. For Gould, music was an "essentially private act" between composer and listener (Gould 1992:180) rather than an opportunity for meaningful communication between performer and listener, as my own approach to liveness (here and in Sanden 2008) suggests.

Nonetheless, and with all apologies to Glenn Gould, I maintain that his recordings do convey performative significance, not just through his brilliant interpretations of musical works, but also through the corporeal liveness so readily apparent in these recorded performances. In Gould's recordings 


\section{Current Musicology}

one can constantly hear not just abstract musical structures (disembodied notes), but also many of the incidental sounds - the noise-involved in Gould's act of sounding out those structures on the piano and with his voice. Gould's recordings provide an excellent opportunity to perceive this corporeal liveness in part due to the close microphone pick-up that he and his recording studio collaborators often employed. Basic microphone technique dictates that the further a microphone is placed from its intended source of sound, the more the reverberant qualities of the recording space will alter that sound. In Gould's case, a close microphone perspective avoided a great deal of room reverberation, resulting in very clear recordings of the sounds emanating directly from the piano and from its immediate vicinity; hence the clarity of Gould's bodily sounds, discussed below. ${ }^{25}$

Gould's intention was not, however, to provide a "close-up" audio perspective on his body making music. On the contrary, and in line with his mind-centered concept of musical communication, Gould deployed this particular use of recording technology in an effort to make the musical structure more apparent to his listeners. He felt that the more customary recording acoustic usually employed for recordings of classical music (at least in his time), which captured the natural resonances of the performance/ recording space, provided an acoustic "halo" around the sound in an effort to make it sound more like a live event. ${ }^{26}$ For Gould, the goal was rather to achieve a certain analytical quality in the sound: one that would allow the listener to hear each individual note as clearly as possible. The added effect of this close-microphone set-up, however, is that we can also hear, very clearly, the noise of Gould's body playing his piano. In addition to his singing, we can hear his physical interaction with his instrument; moreover, we hear the tactility of that instrument: the creaking of his chair as he sways, the percussive nature of hammers hitting strings, the re-dampening of strings as he lifts his foot off the sustain pedal, and the very precise nuances of articulation that are lost in recordings with a more typically reverberant sound. The rest of this essay will address specific examples in Gould's recorded output in which these traces of corporeality are most easily perceived. The liveness of Gould's sounding body in these recordings, audible because of mediatization, draws attention to the significance of Gould's performances and not merely that of his interpretations.

\section{Gould's Voice}

The most obvious evidence of Gould's own performing body in his recordings is his almost constant singing. Gould once told an interviewer that his singing was a reflection of how he thought his phrases should sound, because his fingers never quite got it exactly right (Gould and McClure 1968). At the same time he felt, like many of his critics, that the singing was a dreadful 
distraction from "the music" and wished he could stop doing it without feeling as though it made his playing worse. ${ }^{27}$ Despite attempts to shield this sound from the microphones, his recording engineers were unable to avoid picking it up; it ranges in clarity and loudness from one recording to another. Most of the time, Gould clearly reproduces one of the piano's melodic lines with his singing, often with a character that matches what he is conveying in his playing. The full significance of the liveness inherent in Gould's voice stems largely from the variety in his singing as he demonstrates vocally the nuances of phrasing, dynamics, and articulation to which he aspires in his playing. For it is through the identification of Gould's various vocal stylings that we can also identify a voice emanating from a particular body, rather than just a disembodied voice in the background of a piano recording. I will discuss several moments in Gould's two recordings of Bach's Goldberg Variations (1956; 1982) when the singing is most pronounced, demonstrating how Gould's performing body is represented in his vocalizations.

I have chosen to focus mainly on Gould's Goldberg Variations recordings for several reasons. First, they are perhaps the most prominent recordings of Gould's entire discography. As such, they are highly available and potentially well-known to many readers. Second, Gould's singing is more easily heard here, particularly on the remastered version from which I am working (Gould 2002), than on any other Gould album I have been able to consult. ${ }^{28}$ Third, the composition itself ranges widely in character from one variation to the next, prompting a wide variety of vocal responses from Gould in a rather condensed format. Other recordings by Gould, on the other hand, may also offer clear and engaging singing, but often the character of this singing remains unchanged throughout an entire piece (or at least throughout a movement).

Variation 25 from Gould's 1982 recording demonstrates clearly his tendency simply to hum along with individual voices within the piece's overall texture. The variation, marked Adagio, is lyrically written. In Gould's rendition, it unfolds slowly and clearly. While the variation progresses primarily as a solo treble line accompanied by simple pulses in the left hand voices, Bach does engage in a bit of counterpoint between the treble voice in the right hand and the two voices in the left hand. During the variation, Gould alternates between vocally mimicking the treble voice and one of the accompanying lower voices. Due to the transparent texture of the movement (particularly as realized in Gould's performance), we now hear four clear voices: three from the piano and one from Gould's throat, which variously mimics each of the other three. Most of the time in this variation, Gould projects a basic hum: we hear either a closed " $m$ " sound or a dark long " $e$ " vowel, and very little articulation in the way of hard consonants. This is Gould's singing at its simplest. 


\section{Current Musicology}

Example 1: J.S. Bach, The Goldberg Variations, Variation 25, mm. 1-4, with vocal syllables and breaths transcribed from Gould (2002, Disc 2).
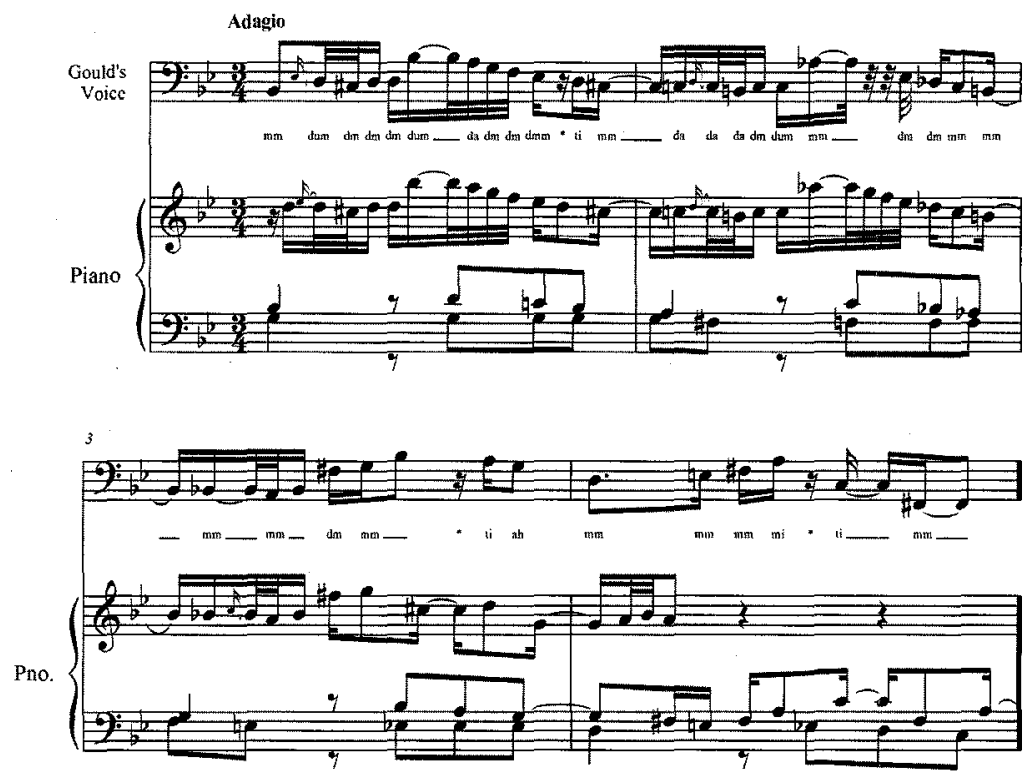

Perhaps the most significant indicators of Gould's corporeality in this variation, however, happen in the moments when Gould is not humming. They occur during the brief moments between his voiced hums when he breathes. The clarity of the recording is such that nearly every time Gould stops for breath, we can hear him inhale. ${ }^{29}$ Example 1 shows a transcription of Gould's vocalizations (along with Bach's notated score) for the first four measures of this variation, including the moments where he breathes (indicated with asterisks).

At this moment, a comparison with Gould's first Goldberg Variations (1956) is intriguing. At two different instances in Variation 15 of that recording, Gould audibly exhales through pursed lips, rather than singing as he usually does. In addition to the whistling air, beginning at 0:05 (m. 2, beat 2), ${ }^{30}$ we quite clearly hear Gould articulate these breaths with a " $\mathrm{t}$ " sound to match the articulation of first the middle and then the upper voice in the piano. (This variation, "Canone all Quinta in moto contrario," is written as a canon in three voices.) Gould similarly exhales "musically" at the start of the variation's second half, beginning at 1:04 (m. 17). In both of these instances, we hear Gould expel and shape this air with his lips, teeth, and tongue. Suddenly the voice we hear on these recordings is not just an ethereal humming sound, but it has a source: a living, breathing body. 
Example 2: J.S. Bach, The Goldberg Variations, Variation 2, mm. 1-8, with vocal syllables transcribed from Gould (2002, Disc 2).
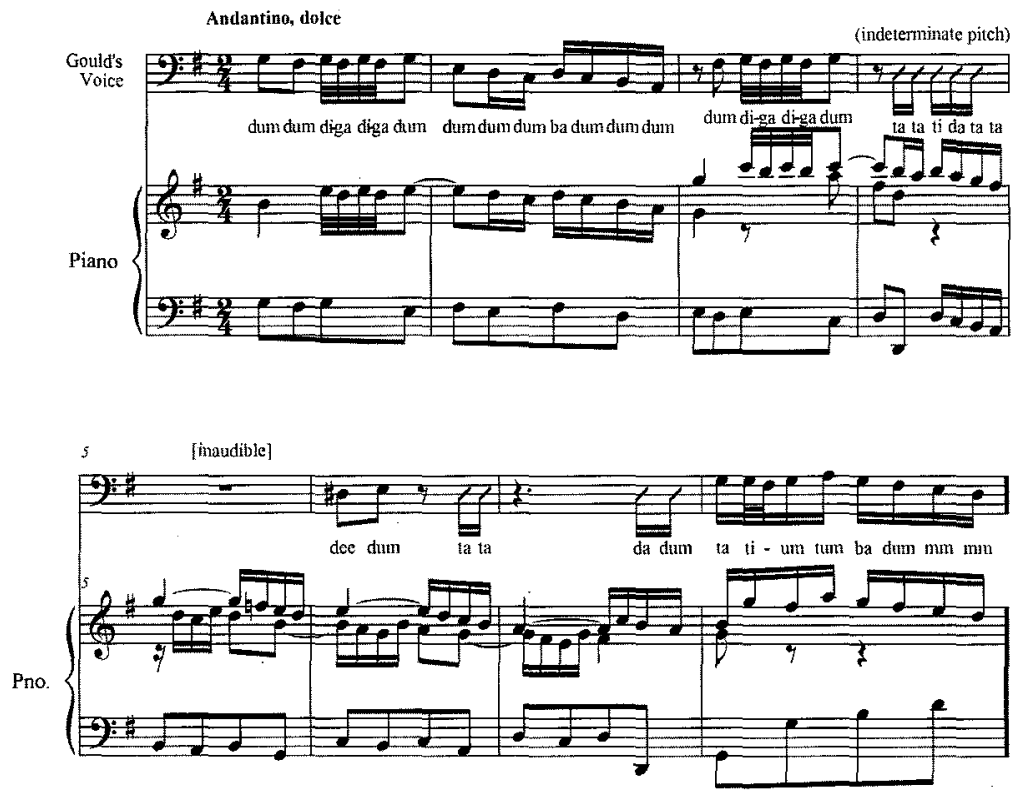

Breathing aside, the singing we hear in both of these variations is rather uneventful compared to some of Gould's recorded vocalizations. For instance, on his 1982 recording of Variation 2, Gould offers a rich variety of vocal sounds in a very short time (the variation runs only forty-seven seconds in this recording). Like Variation 25, Bach writes this variation in three distinct voices. Gould begins his rendition by vocally reproducing the most rhythmically active voice (sometimes in harmony), thus alternating between the top two. Gould's performance of this variation on the piano demonstrates a variety of articulations, moving as it does quite freely between legato and staccato playing and achieving various note lengths in the space between those two extremes. His singing, however, demonstrates even more variety through the different syllables he employs. Gould can clearly be heard singing the syllables, "da," "dee,"'dum," "badum,," ta,"'tum," "ti," "tu," and even "diga-diga-dum," among others (see example 2). The syllables themselves are not particularly significant, so much as the extent to which they further engage Gould's vocal apparatus to give us a sense of what Roland Barthes calls the "grain of the voice": the "tongue, the glottis, the teeth, the mucous membranes, the nose" (Barthes 1977:183). In other words, they reveal the body. At several moments, Gould also clearly increases the intensity of his voice to match his pianistic phrasing. These little vocal swells, brought on by increased airflow and diaphragm support, provide further evidence of Gould's vocal apparatus at work. ${ }^{31}$ We hear the tactility of Gould's body in these vocal sounds. 


\section{Current Musicology}

\section{Gould's Chair}

Vocal sounds emanate from inside a performer's body, providing us with evidence of that performer's interior movements. In addition to the sounds of the piano itself (addressed below), some of Gould's recordings offer even further evidence of his external movements as he plays the piano. On the sleeve of Gould's Beethoven Piano Sonatas, Opus 10 Complete (1965), his producer Thomas Frost offers the following explanation and apology:

For some years now, [Gould] has been merrily fugueing his way through the keyboard works of Bach, Beethoven and Schoenberg to the accompaniment of the strange creakings and groanings of an old, beloved friend-his piano stool. This object of endearment, decrepit and moth-eaten as it is (having reached retirement age long ago), apparently has learned to swing and sway so perfectly with Glenn Gould's body motions that he has stubbornly refused to part with it in spite of all counsel and advice...

[We] hope that you, the consumer, will refuse to be discomforted by some audible creaks that are insignificant in light of the great music-making on this disc. (Gould 1965)

Indeed, throughout this recording, Gould's chair creaks audibly in apparent sympathy with his body's movements as he plays; I would argue that these creaks are a delightful and essential part of the "great music-making on this disc," rather than a distraction from it. As the second movement of Beethoven's Sonata No. 5 in C Minor, op. 10, no. 1 begins, for instance, we hear not only Beethoven's embellished chorale-like opening and Gould's usual accompanimental singing, but also the gentle creaks of Gould's chair as he moves through this opening passage. Throughout the movement the chair's sounds seem to indicate relatively little extraneous body movement on Gould's part: just the occasional shift in weight, perhaps as he depresses or releases a pedal or reaches to a different part of the keyboard. At times (for example, $2: 18 / \mathrm{mm}$. 22-23) the chair's noises occur during moments of relaxed energy in the piece, seemingly indicating a body moving not in sympathy with the movement of the musical line itself, or with the movement of Gould's arms as made necessary by that musical line. ${ }^{32}$ At others, however, it seems apparent that Gould's own range of motion increases with an increased intensity and forward motion in the piece. One of these sequences begins at $2: 53(\mathrm{~m} .51$, beat 2$)$ and continues with added chair noise until a moment of peak musical energy is reached (3:18/m. 60), at which point the chair noises subside along with the energy projected in Gould's playing. A similar demonstration of Gould's bodily movement is represented by increased chair noise beginning around 5:22 (m. 98), as Gould moves 
through a final surge of energy indicated in the score by a rising contour and a crescendo (both typically interpreted in Western musical practice as markers of increased energy). His chair remains almost entirely silent after 5:46 (m. 106), as the forward momentum of the piece slows and finally comes to a halt.

\section{Gould's Piano}

Finally, the body of the piano itself is also quite audible in many of Gould's recordings to an extent uncommon in piano recordings, particularly those made by Gould's contemporaries. Here I speak of the noise of the piano as it is played: not the pitches produced by the depression of keys and the relatively undifferentiated timbre of the piano across its range, but rather the sounds of the piano's mechanical parts coming in contact with one another. These sounds seem to me excellent indicators of the kinetic energy involved in playing the piano: a finger depresses a key, for instance, and a pitch only results once that energy has been transferred into the throwing of a hammer against a string. A piano's noises, then, represent actions taken by the pianist, reminding us of the physical relationship enjoyed between the pianist's body and that of his or her piano. Contrary to Gould's praise of Richter's ability to make the piano's mechanism invisible/inaudible, I find these noises significant and indicative of the vital corporeality of piano performance. Such recognition of the physical relationship established between Gould's body and that of his piano also emphasizes a sort of corporeal co-dependence between musician and instrument. In other words, without one another, both of these bodies remain mute. Music sounds only when they come together in performance.

For my final corporeal hearing, then, I turn to the fifth movement, "Sarabande," in Gould's 1963 recording of Bach's Partita No. 4 in D Major. While we obviously hear the evidence of Gould's fingers in motion, this recording also captures evidence of his feet in motion. The most obvious example of Gould's pedaling is demonstrated by the simple "clunking" noise that occurs when Gould releases his pedal, captured clearly at the end of both the first A section and the A' section (1:04/m. 12 and 4:44/m. 38; the movement's form can be described as A-B-A', with Gould observing the repeat of the first A section).

I also detect in the Sarabande a very beautiful recurring instance of corporeal liveness created by a particular combination of Gould's fingering and pedaling. The second measure of each section in the movement ends with a half note in the treble voice, held over a triad that has been built up from the beginning of the measure. In the A and A' sections, this half 


\section{Current Musicology}

Example 3a: J.S. Bach, Partita No. 4 in D Major, Sarabande, mm. 2-3, b. 1.

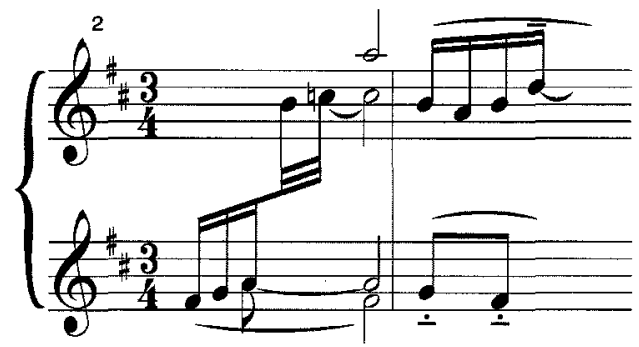

note, an a", ${ }^{33}$ doubles the third in a diminished iii chord that moves to the subdominant in the next measure (see example $3 \mathrm{a}$ ). In the $\mathrm{B}$ section, the half note, an $\mathrm{e}^{\prime \prime}$, functions as the seventh degree in a major-minor seventh chord leading to a G-major chord, which is spelled out in the first beat of the next measure (see example $3 \mathrm{~b}$ ). Each time this moment occurs in his performance $(0: 08 / \mathrm{m} .2,1: 11 / \mathrm{m} .2,2: 18 / \mathrm{m} .14,3: 48 / \mathrm{m} .30)$, Gould holds the sustain pedal down until he has clearly voiced each note in the measure. At some point before he releases the sustain pedal, he also releases both of the keys he has been depressing with his left hand. He then releases the sustain pedal so that we only hear the top two notes, emphasizing the inverted minor third between $\mathrm{c}^{\prime \prime}$ and $\mathrm{a}$ " in the $\mathrm{A}$ and $\mathrm{A}^{\prime}$ sections, and the minor seventh between $f^{\prime \prime}$ and $\mathrm{e}^{\prime \prime}$ in the $\mathrm{B}$ section. Finally, he releases the lower note in his right hand so that we hear the top note ringing on its own before he moves on to the next measure.

The first three times Gould performs this little act of manual and pedal precision in the Sarabande (that is, in both iterations of the A section and in the $B$ section), we hear it exactly as I imagine he intended, and the harmonic importance of those particular notes is emphasized according to Gould's interpretation. When this moment occurs in the $\mathrm{A}^{\prime}$ section, however, another acoustic reminder of the physical contact between performer and instrument sounds. In this instance $(3: 51 / \mathrm{m} .30)$, Gould releases the pedal and the c"key in such a way that the felt intended to dampen the strings corresponding to that key actually causes a momentary "shimmer" on that note. Such an effect is created when felts are held, by way of a partially depressed sustain pedal, just slightly off the strings - -far enough away that the strings are afforded more room to vibrate, but still close enough to the strings to restrict that vibration somewhat. Thus, before our attention is drawn to the sustained a" at the end of this measure, it is first drawn to the c" beneath it, which Gould inadvertently emphasizes when he releases the sustain pedal. Such an audible effect, inadvertent or not, is a clear reminder of the physical process of playing the piano and thus another strong indicator of the significance of corporeality on this particular recording. 
Example 3b: J.S. Bach, Partita No. 4 in D Major, Sarabande, mm. 14-15, b. 1.

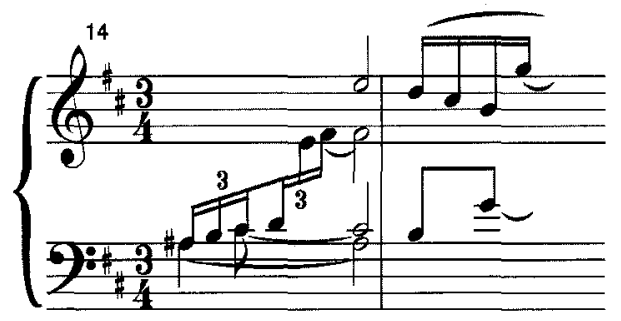

\section{Conclusion}

I have presented in this article corporeal hearings of several of Gould's recordings. I offer these interpretations with particular awareness of how they relate to an abiding mind/body binarism in discussions of Western music and in Western epistemology more generally. Particularly in light of Gould's well-established mind-centered persona (promoted both by Gould's commentators and through his own efforts) these hearings suggest that even the most "cerebral" of musicians can be heard corporeally. In Gould's case, his particular engagement with recording technology affords us greater access to the qualities of corporeal liveness apparent in his performances, despite his own views on the role of performing bodies in musical practice.

My discussion of Gould's recordings leads me to confront accounts of recordings that present them as representations of disembodied music. While many concerns about the alienating potential of technology in music are well placed, such accounts often ignore the very real potential in mediatized music for increased communication of corporeal — and thus human-significance. Relationships between liveness and mediatization must be reconsidered so that, where appropriate, mediatization may be construed as a productive way to project new and necessary understandings of musical meaning. A static live/recorded binarism, in light of such arguments, no longer seems appropriate. By hearing Glenn Gould's body in his recordings, we hear his liveness. Not only can we then rethink our common conceptions of Gould's musicianship, but also our common conceptions of recorded music. An awareness of liveness reminds us of the sociality of music by emphasizing its performance, even when conventional indicators of performance become reconfigured by the very acts of mediatization I emphasize here. In an era of potentially de-socializing technological practices (internet shopping, automated bank tellers, anonymous on-line communications, etc.), such a reminder seems increasingly important. 


\section{Current Musicology}

\section{Notes}

I am most grateful for the support and input of a number of people throughout the process of writing this article, chief among them: Jonathan Burston, Nicholas Cook, Omar Daniel, Carolyn Herrington, Sandra Mangsen, Richard Parks, and Rick Semmens.

1. Among the many important accounts of liveness, see Feuer (1983) for an account of televisual liveness, Gracyck (1996) and Auslander (1999) for discussions of liveness in rock music, and Emmerson (2007) for an extensive treatise on liveness in electroacoustic music.

2. These categories are: temporal liveness, spatial liveness, liveness of fidelity, liveness of spontaneity, corporeal liveness, interactive liveness, and virtual liveness.

3. As Lydia Goehr (1992) suggests, since ca. 1800 works of Western art music have generally been considered to be unique (and entirely reified) objects representative of a specialized genius labour (composition). The usual existence of these works in written scores reiterates this reification.

4. Hoffmann's views are particularly significant to my account of this historically consistent perspective on music and mind, due to the extent to which his writings served as models for a developing style of Germanic music criticism in the nineteenth century (see Strunk's introduction to Hoffmann [1998:1193]). Twentieth-century musicology, and evidently Gould's own approach to the evaluation of music, grew out of this very tradition.

5. For a further discussion of phallogocentrism, see especially Derrida (1979).

6. Other significant answers to the troubling neglect of musical embodiment in Western musical discourse include David Lidov's "Mind and Body in Music" (1987); George Fisher and Judy Lochhead's "Analyzing from the Body" (2002; see below, n. 22); Michelle Duncan's "The Operatic Scandal of the Singing Body: Voice, Presence, Performativity" (2004); and Tracy McMullen's “Corpo-Realities: Keepin' It Real in 'Music and Embodiment' Scholarship" (2006; see below, n. 20).

7. Attali links this concept further to relationships of power as they are carried out in the social practice of music, particularly focusing on the increasing commodification of music through history. While I will not engage with Attali's economic discussions, I believe that his poetic use of the word noise (bruit, in the original French) fits well in the context of a mind/body discussion of musical value.

8. Columbia Masterworks was the "classical" division of the Columbia record label. This division became CBS Masterworks in 1980; following the 1987 purchase of CBS by Sony, the classical division was renamed Sony Classical in 1990. Current releases of Gould's recordings are thus issued and owned by Sony Classical. See "A Brief History of the Sony Classical Label," Sony Classical, http://www.sonyclassical.com/about/history.html (accessed May 25, 2008) for further details.

9. The reference here is to the so-called Second Viennese School, usually considered to comprise Arnold Schoenberg and his pupils, Anton Webern and Alban Berg. Gould was about to publish a short monograph about Schoenberg (Gould 1964) and had also given several talks on the topic of serial music.

10. Indeed, as I will discuss below, this is how Gould often described his relationship with the piano and with the music he played.

11. My own previous work on Gould is guilty of the same bias toward his philosophies and ideas, at the expense of any serious discussion of the physical act of playing. See Sanden (2003a, 2003b, 2005). As I suggest below, while it is important to address the very real connection between mind and body in music, the prevailing paradigm heavily favors the mind at great detriment to bodies. This essay attempts to correct the balance, not only in my own work, but in Gould scholarship in general. 
12. Late in his career, Gould struggled to maintain complete control over his left hand. Roberts's comments on this struggle present a clear image of a mind under attack by a body: "Gould's effort to control every function of his performing mechanism made superhuman demands on his mind and it seems that, at times, when he relaxed these demands and concentrated on the music, he achieved better results" (Roberts 1999:25).

13. Gould worked very hard to promote a particular image of himself. My own impression is that at least some of his mannerisms and pronouncements were as much adopted for the sake of this image as they were reflections of his true thoughts and feelings. Nevertheless, the persona Gould crafted for himself was accepted by a vast public. As I am concerned here with the Gould discourse more than with the conditions of Gould's private reality (whatever they may have been), I will relate his professed beliefs without questioning their veracity.

14. Elsewhere (Gould and Braithwaite 1999:41), Gould explains that one of the reasons he avoids so much Romantic piano repertoire is that it requires more arm strength in fortissimo passages than he can generate given his low seating position.

15. As discussed above (n. 12), Roberts relates that in 1977, Gould actually did suffer from a loss of manual control. He explained to Roberts that "his hands were 'out of sync' with his mind" (Roberts 1999:24).

16. See Bazzana (2003:194-97) for further discussion. During the ensuing legal discussions, Gould argued that he was of a particularly frail disposition and that he had previously warned the people at Steinway that they should accordingly avoid unnecessary physical contact with him.

17. Audio imaging is the term usually applied to the practice of creating a spatially visualizable sound field on a recording, through stereo placement, careful use of reverberation (to create the impression of distance), and other techniques.

18. Compression is a sound filtering technique that reduces the overall dynamic range of a sound signal, essentially boosting the average dynamic level of the entire signal while lowering that of the stronger parts of the signal. By flattening the signal in this way, this technique obscures many of the corporeally identifying noises that are easier to hear with a more highly differentiated dynamic spectrum.

19. Derrida's Of Grammatology (1976) is perhaps the most significant and foundational text in which the tenets of logocentrism are explained.

20. For instance, see Tracy McMullen's discussion of "Recorded versus Embodied Performance" (2006:61-64), in which she locates the central significance of "embodied performance" in that performing body's ability to be seen.

21. In this, parallels with phenomenologist Maurice Merleau-Ponty's foundational arguments are evident. For instance, Merleau-Ponty wrote: "The perceiving subject is not [an] absolute thinker; rather, it functions according to a natal pact between our body and the world, between ourselves and our body" (1964:6). More recently, neuroscientists have provided empirical evidence to support the assertion that "a disembodied mind as such does not exist" (Leman 2008:13). See, for example, Damasio (2000) and Jeannerod (2002).

22. See also Fisher and Lochhead (2002:47), who do not offer a new label, but argue that listeners "engage musical sounds with their bodies in the creative and improvisatory process of understanding. Although listeners' embodied experience may involve little or no visible movement, their performative enaction of musical meaning has an intercorporeal dimension."

23. A listener's responses need not be strictly mimetic, however. Even our descriptions of music as "moving" (ascending passages, accelerating tempi, etc.) illustrate the extent to which we understand musical experiences according to our existing physical knowledge of 


\section{Current Musicology}

corresponding motions. Because this connection already exists, musical lines that accelerate, descend, ascend, or follow any other recognizable pattern of motion re-engage with listeners' embodied experiences of those particular movements.

24. See, for example, Gould and McClure (1968).

25. As Bazzana (1997:240,247) discusses, Gould's usual microphone placement, particularly for the contrapuntal works he favored, was about five feet from the piano, which provided a closer, "drier" perspective than that demonstrated in most classical piano recordings by his contemporaries.

26. It is widely accepted that art music recordings, particularly in Gould's time, embrace a "documentary" aesthetic (Toynbee 2000:70) in an effort to replicate the concert situation as closely as possible.

27. In an essay on jazz pianist Keith Jarrett's "extraneous" singing and gesticulating that has many parallels with the current essay, Jairo Moreno links the types of criticisms aimed at Jarrett and Gould (and, I would suggest, Gould's own criticisms of his singing) with an abiding system of discipline within Western musical practice and discourse, that "seeks ... to control movement and gesture. These elements are controlled because there is in place a conventional belief in the role of the performer; thus the articulations and gesticulations of the body are part of the mechanics of reproduction, but not, perversely enough, of the articulation of meaning" (Moreno 1999:81).

28. Regarding my choice of recorded sources, I ought to point out that I have sought out recordings in which Gould's corporeal liveness is most perceptible, regardless of format. In some cases, the original vinyl issues have proven better sources in this regard, and in others, $\mathrm{CD}$ reissues seem to portray these elements more clearly. Further, I have listened to these materials both in front of a conventional stereo speaker array and through headphones (though in most cases, headphone listening reveals more detail than "open-air" listening). I have also listened to each recording with a variety of equalization settings, experimenting until these traces of Gould's body are most audible. I have adopted such a varied approach to these sources, rather than observing a strict listening methodology, in order to reflect as much as possible the variety of contexts in which any group of Gould listeners may encounter these recordings. As what I propose in this essay is a strategy for hearing corporeal liveness in recordings, it is important to emphasize that listeners may employ their recording playback technology in whatever way necessary to make that corporeal liveness most evident. It is significant, however, that often listeners must indeed work very hard to hear even faint traces of corporeality in recordings. This is because, in many cases, recording technicians work very hard themselves to scrub these sounds from recordings, precisely for the reasons outlined by Corbett above: the people making these recordings subscribe to a "fantasy of absolutely independent music." As Corbett further suggests, and as Burston (1998) clearly argues, this fantasy of independent music and its resulting erasure of the sounds of performing bodies often align with the financial interests influencing commercial musical production.

29. Particularly audible breaths occur at 0:07, 0:26, 1:18, 4:30,4:45, and 5:16 (timings refer to the progression of the individual variation-separately tracked on Gould 2002, Disc 2 -rather than to the progression of the entire work).

30. I make reference in this essay both to timings in recordings and to measure numbers in written scores. I include measure numbers as a convenience to readers, but also with a very particular goal in mind: elements of liveness are not necessarily encoded in a work as it is represented in a score, but may very well derive-as in Gould's case-from a performer's physical efforts to represent that score in performance. The score, then (to appropriate Nicholas Cook's [200I, 2003] arguments about scores and performances), is a potential script for liveness. 
31. At 0:09 in Variation 5 (Gould 2002, Disc 2), a similar vocal swell allows us momentarily to hear Gould's voice clearly over a rather busy piano part, which obscures his vocalizations throughout the rest of the variation. This increase in vocal energy indicates an embodied voice asserting itself over and above the sounds of what Gould would have considered the "music" (i.e., the pitches of the composition as played on the piano).

32. At this particular moment in the recording (due not only to Beethoven's indications but also to Gould's realization of those indications), the left hand remains silent while the right hand ascends delicately and softly through a slowly moving sixteenth note line, to arrive, pianissimo, at m. 24.

33. I adopt here the Helmholtz system of octave designation, with $\mathrm{c}$ beginning the octave below middle $c$, c' the octave at middle $c, c$ " the octave above that, etc. See Grove Music Online, s.v. "Pitch Nomenclature" (by L. S. Lloyd and Richard Rastall), http://www.grovemusic.com/ (accessed June 15,2008) for further explanation.

\section{References}

Attali, Jacques. [1977] 1985. Noise: The Political Economy of Music, translated by Brian Massumi. Minneapolis and London: University of Minnesota Press.

Auslander, Philip. 1999. Liveness: Performance in a Mediatized Culture. London and New York: Routledge.

- 2005. At the Listening Post, Or, Do Machines Perform? International Journal of Performance Arts and Digital Media 1 (1): 5-10.

Barthes, Roland. [1972] 1977. The Grain of the Voice, translated by Stephen Heath. In Image-Music-Text, 179-89. New York: Noonday Press.

Baudrillard, Jean. 1981. For a Critique of the Political Economy of the Sign, translated by Charles Levin. St. Louis: Telos Press.

Bazzana, Kevin. 1997. Glenn Gould: The Performer In the Work. Oxford: Clarendon Press.

- 2003. Wondrous Strange: The Life and Art of Glenn Gould. Toronto: McClelland and Stewart.

Burston, Jonathan. 1998. Theatre Space as Virtual Place: Audio Technology, the Reconfigured Singing Body, and the Megamusical. Popular Music 17 (2): 205-18.

Cook, Nicholas. 2001. Between Process and Product: Music and/as Performance. Music Theory Online 7 (2). Accessed April 23, 2008. http://www.societymusictheory.org/mto/ issues/mto.01.7.2/mto.01.7.2.cook.html.

-2003. Music as Performance. In The Cultural Study of Music: A Critical Introduction, edited by Martin Clayton, Trevor Herbert, and Richard Middleton, 204-14. London and New York: Routledge.

Corbett, John. 1990. Free, Single, and Disengaged: Listening Pleasure and the Popular Music Object. October 54: 79-101.

Cox, Arnie. 2001. The Mimetic Hypothesis and Embodied Musical Meaning. Musicae Scientae 5 (2): 195-212.

Cusick, Suzanne. 1994. Feminist Theory, Music Theory, and the Mind/Body Problem. Perspectives of New Music 32 (1): 8-27.

Damasio, Antonio R. 2000. The Feeling of What Happens: Body and Emotion in the Making of Consciousness. New York: Harcourt Brace.

Derrida, Jacques. [1967] 1976. Of Grammatology, translated by Gayatri Chakravorty Spivak. Baltimore, MD: Johns Hopkins University Press.

[1978] 1979. Spurs: Nietzsche's Styles, translated by Barbara Harlow. Chicago and London: University of Chicago Press. 


\section{Current Musicology}

Duncan, Michelle. 2004. The Operatic Scandal of the Singing Body: Voice, Presence, Performativity. Cambridge Opera Journal 16 (3): 283-306.

Emmerson, Simon. 2007. Living Electronic Music. Aldershot, UK, and Burlington, VT: Ashgate Publishing.

Feuer, Jane. 1983. The Concept of Live Television: Ontology as Ideology. In Regarding Television: Critical Approaches-An Anthology, edited by E. Ann Kaplan, 12-22. Los Angeles: American Film Institute.

Fisher, George, and Judy Lochhead. 2002. Analyzing from the Body. Theory and Practice 27: 37-67.

Goehr, Lydia. 1992. The Imaginary Museum of Musical Works: An Essay in the Philosophy of Music. Oxford and New York: Oxford University Press.

Gould, Glenn. 1964. Arnold Schoenberg: A Perspective. Cincinnati: University of Cincinnati Press.

1967. Liner notes accompanying Canadian Music in the 20th Century (Columbia Masterworks 32110046, LP).

- 1992. Glenn Gould: Selected Letters, edited by John P. L. Roberts and Ghyslaine Guertin. Oxford and New York: Oxford University Press.

1999a. Forgery and Imitation in the Creative Process. Lecture given to the Summer School of the University of Toronto on July 2, 1963. Printed in The Art of Glenn Gould: Reflections of a Musical Genius, edited by John P. L. Roberts, 205-21. Toronto: Malcolm Lester Books.

1999b. Sviatoslav Richter. Script for documentary film. Printed in The Art of Glenn Gould: Reflections of a Musical Genius, edited by John P. L. Roberts, 50-54. Toronto: Malcolm Lester Books.

Gould, Glenn, and Jim Aikin. [1980] 1999. Provocative Insights from a Controversial Pianist: Gould in Conversation with Jim Aikin. In The Art of Glenn Gould: Reflections of a Musical Genius, edited by John P. L. Roberts, 259-78. Toronto: Malcolm Lester Books.

Gould, Glenn, and Bernard Asbell. [1962] 1999. The Artist Speaks for Himself. In The Art of Glenn Gould: Reflections of a Musical Genius, edited by John P. L. Roberts, 185-95. Toronto: Malcolm Lester Books.

Gould, Glenn, and Dennis Braithwaite. [1959] 1999. "I'm a Child of Nature": Gould in Conversation with Dennis Braithwaite. In The Art of Glenn Gould: Reflections of a Musical Genius, edited by John P. L. Roberts, 38-46. Toronto: Malcolm Lester Books.

Gould, Glenn, and Alan Rich. [1959] 1999. The Composing Career That Eluded Gould and the Performing Career That Did Not: Gould in Conversation with Alan Rich. Transcription of a recorded radio interview (1959). Printed in The Art of Glenn Gould: Reflections of a Musical Genius, edited by John P. L. Roberts, 132-52. Toronto: Malcolm Lester Books.

Gould, Glenn, and Vincent Tovell. [1960] 1999. At Home with Glenn Gould: Gould in Conversation with Vincent Tovell. Transcription of a recorded radio interview (1960). Printed in The Art of Glenn Gould: Reflections of a Musical Genius, edited by John P. L. Roberts, 66-88. Toronto: Malcolm Lester Books.

Gracyck, Theodore. 1996. Rhythm and Noise: An Aesthetics of Rock. Durham, NC, and London: Duke University Press.

Hayles, N. Katherine. 1999. How We Became Posthuman: Virtual Bodies in Cybernetics, Literature, and Informatics. Chicago and London: University of Chicago Press.

Hoffmann, E.T.A. [1813] 1998. Beethoven's Instrumental Music, translated by Oliver Strunk. In Source Readings in Music History, revised edition, edited by Oliver Strunk and Leo Treitler, 1193-98. New York: Norton.

Jeannerod, Marc. 2002. La Nature de l'esprit: Sciences cognitives et cerveau. Paris: Jacob.

Le Guin, Elisabeth. 2006. Boccherini's Body: An Essay in Carnal Musicology. Berkeley and Los Angeles: University of California Press. 
Leman, Marc. 2008. Embodied Music Cognition and Mediation Technology. Cambridge, MA, and London: MIT Press.

Leppert, Richard. 1993. The Sight of Sound: Music, Representation, and the History of the Body. Berkeley and Los Angeles: University of California Press.

-2007. The Musician of the Imagination. In Sound Judgment: Selected Essays. Aldershot, UK, and Burlington, VT: Ashgate Publishing.

Lidov, David. 1987. Mind and Body in Music. Semiotica 66 (1): 69-97.

McClary, Susan. 1991. Feminine Endings: Music, Gender, and Sexuality. Minneapolis and London: University of Minnesota Press.

McMullen, Tracy. 2006. Corpo-Realities: Keepin' It Real in "Music and Embodiment" Scholarship. Current Musicology 82: 61-80.

Mead, Andrew. 1999. Bodily Hearing: Physiological Metaphors and Musical Understanding. Journal of Music Theory 43 (1): 1-19.

Merleau-Ponty, Maurice. 1964. The Primacy of Perception and Other Essays on Phenomenological Psychology, the Philosophy of Art, History and Politics, edited by James M. Edie. Evanston, IL: Northwestern University Press.

Moreno, Jairo. 1999. Body'n'Soul?: Voice and Movement in Keith Jarrett's. Pianism. The Musical Quarterly 83 (1): 75-92.

Page, Tim. 2002. Glenn Gould: A State of Wonder. Liner notes accompanying Glenn Gould: A State of Wonder: The Complete Goldberg Variations 1955 \& 1981 (Sony Classical/Legacy S3K 87703).

Parmenter, Ross. 1956. Concert is Given at Canadian Fete: Glenn Gould is Piano Soloist, Conductor and Annotator of Program at Stratford. The New York Times (July 10): 26.

Payzant, Geoffrey. 1978. Glenn Gould: Music and Mind. Toronto: Van Nostrand Reinhold.

Roberts, John P. L. 1999. The Art of Glenn Gould: Reflections of a Musical Genius. Toronto: Malcolm Lester Books.

Sanden, Paul. 2003a. Glenn Gould and Recording Technology: Linking Popular and Classical Recording Practices. Paper presented at the International Conference of the International Association for the Study of Popular Music. Montreal, QC (July 3).

. 2003b. Glenn Gould and The Beatles: Creative Recording, 1965-1968. M. Mus. Thesis, The University of Western Ontario.

__ 2005. Modern Performance Through a "Gouldian" Lens: Glenn Gould, Technology, and Performance Contexts. Paper presented at the annual conference of the Canadian University Music Society. London, ON (May 31).

- 2008. Performing Liveness: Musicians, Machines, and Mediatization. PhD dissertation, The University of Western Ontario.

Schonberg, Harold. 1959. Colorful Canadian: Glenn Gould, Pianist, Presents Program. The New York Times (February 14): 14.

Sterne, Jonathan. 2003. The Audible Past: Cultural Origins of Sound Reproduction. Durham, $\mathrm{NC}$, and London: Duke University Press.

Strunk, Oliver. 1998. Introduction to "Beethoven's Instrumental Music," by E. T. A. Hoffmann. In Source Readings in Music History, revised edition, edited by Oliver Strunk and Leo Treitler, 1193. New York: Norton.

Thornton, Sarah. 1995. Club Cultures: Music, Media and Subcultural Capital. London and New York: Routledge.

Todd, Neil P. McAngus. 1995. The Kinematics of Musical Expression. Journal of the Acoustical Society of America 97 (3): 1940-49.

Toynbee, Jason. 2000. Making Popular Music: Musicians, Creativity and Institutions. London: Arnold. 


\section{Current Musicology}

\section{Discography}

Gould, Glenn. 1956. Bach: The Goldberg Variations. Columbia Masterworks ML 5060.

- 1963. Bach: Partitas Nos. 3 \& 4/Toccata No. 7. Columbia Masterworks MS 6498. 1965. Glenn Gould Plays Beethoven Piano Sonatas, Opus 10 Complete. Columbia Masterworks MS 6686.

1982. Goldberg Variations: BWV 988. CBS Masterworks IM 37779.

2002. Glenn Gould: A State of Wonder: The Complete Goldberg Variations 1955 \& 1981. Sony Classical/Legacy S3K 87703.

Gould, Glenn, and John McClure. 1968. Glenn Gould: Concert Dropout, in Conversation with John McClure. Recorded interview. Columbia Masterworks BS 15. 